\title{
Polite like an Egyptian? Case Studies of 'Politeness' in the Late Ramesside Letters
}

\author{
Kim Ridealgh, UEA
}

\section{Abstract}

The Late Ramesside Letters (LRL), a corpus of over 70 personal communications written in Late Egyptian, are one of the most complete letter collections from ancient Egypt (1099-1069 BC). A key feature of ancient Egyptian letter writing is the adherence to the social positions of, and relationships between, the interlocutors, allowing scholars to reconstruct the hierarchical network of individuals directly and indirectly included in the corpus. How then can modern scholars discern what was considered to be 'polite' communicative behaviour within these relationships and how can developments in historical politeness help us do this? This article will explore three case studies surrounding different aspects of politeness research: first-order politeness, facework, and discernment politeness, in order to explore the phenomenon of 'politeness' in Late Egyptian and reflect on the suitability of current 'politeness' frameworks for the analysis of the Late Ramesside Letters.

Keywords: Late Egyptian, Late Ramesside Letters, facework, politeness 1 , discernment politeness

\section{Introduction}

The study of politeness phenomena is difficult in any language system outside of the evaluator's own socio-cultural group. These difficulties become more acute when the culture under study is in the remote past. Written culture grew and evolved in Egypt from around 3000 BCE onwards, and although thousands of texts have been discovered, many are damaged or not properly published, additionally, many do not include information that would make it possible to assign a date or place to the text (Culpeper 2009: 182; Kádár \& Culpeper 2010: 17). These are fundamental issues for scholars analysing any historical period, but are difficulties that are heightened when focusing on the ancient world; climate and time are not good preservers of documents, many of which are written on papyrus. Of course this highlights another key issue that separates the analysis of the ancient world and the modern; we are solely limited to written data (Bax 1983: 18; Jacobs \& Jucker 1995: 6-7; Kerbrat-Orecchioni 2011: 138).

This paper will utilise the corpus of epistolary texts known as the Late Ramesside Letters (c.1099-1069 BCE) to explore the phenomenon of 'politeness' in Late Egyptian through the presentation of three case studies, focusing on first-order politeness, facework, and discernment politeness. Like the field of historical (im)politeness research itself (see discussions by Kádár \& Culpeper 2010: 9-25; Bax \& Kádár 2011: 14-17), the study of politeness phenomena in Late Egyptian is in its infancy, and like the majority of languages under review in this edition, Brown \& Levinson's framework plays a fundamental role in analysing examples of 'politeness' because it is the most complete. When dealing with a largely fragmented and interrupted dataset, it is not possible to apply other theories of politeness, such as the common sense approach voiced by Ide $(1989 ; 1992)$ and Blum-Kulka (1992). After all, we only have limited understanding of the socio-cultural foundation of ancient Egyptian society and have no basis to reconstruct how the Egyptians projected a concept of common sense, let alone possess the metalanguage to express this. Certainly, Brown \& Levinson's framework is that of facework and for this purpose it is, to an extent, suitable for analysing Late Egyptian due to the letters being used to support social relationships between interlocutors. However, it must be kept in mind that not all of Brown \& Levinson's frame work is applicable, for example, Egypt had a strict hierarchical system. As such power was a fixed factor of superior/subordinate relationships and not negotiable in dialogue. Additionally, there is no way to establish the weightiness of a 'face-threatening' act (FTA), or if/how the Egyptians ranked impositions.

Within Egyptology, the first scholar to consider 'politeness' was Fox (1983), who examined correct ways of behaving in didactic texts. Yet, it was Sweeney who first highlighted the importance of 
Politeness Theory, in particular facework, in her seminal 2001 monograph on pragmatic features of letter writing in Late Egyptian; introducing the framework for the first time to the study of ancient Egypt. Sweeney (2001: 232-249) concluded in her study that she preferred the term courtesy, rather than 'politeness', breaking it down into status, cost \& benefit, and connection, and certainly these features played an essential part in performing communicative acts and supporting relationships in ancient Egypt. Although, Sweeney's approach does present some limitations (discussed further in section 4), her research has been instrumental in highlighting the need for deeper study in the area of politeness phenomena, and heavily influences my own research (Ridealgh 2013).

\title{
2. The Late Ramesside Letters
}

Letters are fundamental to understanding social relationships due to their nature as authentic communication between identifiable specific correspondents, which better reflect spoken language than other genres of text (Bakir 1970: 14-15; Biber \& Finegan 1989; 1992: 689; Donker van Heel \& Haring 2003: 112-115; Gibson \& Morrison 2007: 3). Letters provide access to early patterns of interaction and can be studied from the interactional perspective (Palander-Collin et al 2009:5; Kádár 2010: 120). As Palander-Collin (2009: 53-54) comments

\begin{abstract}
'although it is seldom possible to follow a full sequence of letters between the same writers, letters nevertheless show glimpses of past interactions and provide valuable material for the study of earlier patterns of interaction. The letter genre allows us to observe how authorial selves and participants' relationships change from one letter to another and how such changes affect the linguistic style adopted by the writer. The same can be send of the linguistic mechanisms used by the writer to maintain their relationship with the recipient' (see also Jacobs \& Jucker 1995: 8).
\end{abstract}

This is true also of the Late Ramesside Letters, which are written in Late Egyptian, a stage of Ancient Egyptian that reflects far more of the spoken language used at the time. ${ }^{i}$ The Late Ramesside Letters were written at the end of the 20th Dynasty (end of the New Kingdom), during the reign of Ramesses XI (c.1099-1069 BCE) when Thebes (modern-day Luxor) was facing a turbulent period of social and economic anxiety. The letters form a corpus of over seventy published texts (Černý 1939; Wente 1967; 1990; Janssen 1991; Demarée 2006), one of the largest corpora of letters from ancient Egypt as a whole, and consist of a collection of personal communications sent between various inhabitants of the Theban west bank. The community that features in the letters included the key administrative and scribal staff that lived and worked around the mortuary temple of Ramesses III at Medinet Habu. The majority of the letters were written by or sent to the necropolis scribe Dhutmose, who was one of the main administrators based at Medinet Habu and came from a prominent scribal family (Černý 1973: 144; Bierbrier 1975: 41). His son Butehamun, with whom he communicated frequently, was also a necropolis scribe and his father's deputy whilst Dhutmose accompanied his superior, the General Piankh, on military campaign south into Nubia (modern North Sudan). Many of the letters are sent between these two men and detail not only their relationship but also their daily activities and duties as scribes for the royal necropolis (now known as the Valley of the Kings).

The format of the Late Ramesside Letters is standardised, consisting of a formal introduction or salutation, followed by the main body, optional conclusion formulae, and then the address (Bakir 1970: vii). Social hierarchy permeates the construction of the letters themselves — just as it did through ancient Egyptian culture - where, even on a fundamental level, a fixed linguistic etiquette is apparent when communicating with individuals who are socially superior or subordinate to the sender of the letter. When writing to one's subordinate a more dominant letter format is adopted, requiring a short formal introduction, or none at all, and then a higher frequency of imperative request acts within the text. On the other hand, when a subordinate individual writes to his superior, a longer formal introduction is necessary alongside more fawning language (Sweeney 2001: 234), and someone socially inferior is more likely to perform a higher frequency of information acts or formal, indirect request acts (Ridealgh 2013; similar patterns are found in Hebrew biblical narrative, see Bridge [2010: 524-547]). 
Sweeney's study of pragmatic features of letter writing in Late Egyptian also highlights differences in the type of grammatical constructs used by superiors and subordinates. She (2001: 53) argues, through a detailed compilation of grammatical features, that the following forms are used by superiors to subordinates: imperatives; $j h \underline{h} s d m=k$; wnn $t 3 y=j \check{s}^{c} . t<h r>s p r r=k j w=k<h r>s \underline{d m}$; the third future; the initial prospective $s \underline{d} m=f$; second tenses; and conjunctives. Conversely, she then states that the following forms are used by subordinates to their superiors: imperatives; $j \underline{h} s \underline{d} m=k$ (rarely); the third future; and conjunctives. Social hierarchy supports the very nature of the communication in the letters, both grammatically and structurally, clearly defining the superior/subordinate relationship. Communication between socially equal individuals did of course occur, and in letters between those of equal stature, a mixture of superior and subordinate grammatical and structural forms were employed.

\section{Case Studies of 'Politeness' in the Late Ramesside Letters}

In this article it is not possible to provide a complete overview of 'politeness' in Late Egyptian. Instead, key areas will be highlighted and discussed using examples from the Late Ramesside Letters. Within these case studies, I will argue that within the microcosm of the community portrayed in the letters, social hierarchy is fundamental to the construction of the communicative events. Kádár \& Culpeper (2010: 13) highlight that 'we cannot assume that concepts developed for modern politeness theories and frameworks can be applied straightforwardly to historical data'. This is certainly true for Late Egyptian. During the three case studies I will reflect on the compatibility of current 'politeness' frameworks and problems faced when attempting to better understand politeness phenomena in Late Egyptian. At the moment for Late Egyptian it is necessary to experiment with different approaches to 'politeness' research, in order to see which frameworks and approaches are most suitable for extracting new information from the letters; for the most part this often means utilising more than one framework simultaneously (Kádár 2010: 142).

\subsection{Politeness ${ }_{1}$ : Understanding Politic Behaviour}

There is a current trend in historical politeness studies to trace back the underlying meanings of 'politeness' in the language system under study, including phraseology and user evaluations (Junker 2010: 176-181;Watts 2011: 105; Bax \& Kádár 2011: 5; Terkourafi 2011). This type of first-order politeness study stems from the work of Richard Watts, who stresses that

\footnotetext{
'the only adequate way of theorising about 'politeness' is to see it not as an essence beyond emergent social practice, but rather as an extraordinary complex, constantly fluctuating and ultimately unstable cognitive concept that we make use of and frequently adapt and transform when involved in emergent social practice. In other words, a 'politeness' theory can only be a first-order theory of politeness which will form part of a wider constructionist theory of how we learn about and make sense of the worlds that we are constantly creating throughout the whole of our lives. We must judge what social behaviour is or has been, for each of us individually, 'polite', (Watts 2011: 105).
}

Watts (2011: 108-110) employs a socio-cognitive approach to analysing Politeness ${ }_{1}$, creating metaphorical social frames in the interaction based upon an individual's social experiences, which are embedded in long-term memory, and examines how these aspects help to produce behaviour judged to be appropriate to the social practice engaged in. He calls these knowledge frames 'politic behaviour', which result in individuals (i) producing appropriate behaviour and (ii) showing consideration (Watts 2011: 128). This implies that the creation of these politic behaviour knowledge frames is based on a wider understanding of politic behaviour in the individual's society, behaviour that is quantified and qualified by that culture.

Yet, what happens when the primary documentation for viewing this phenomenon is simply not there? When we consider ancient Egyptian texts as a whole, our scope of the 'politeness' knowledge frame is somewhat limited. This then effects the way that we can interpret first order politeness as expressed by the users of the system themselves, users that primarily come from an elite, literate social class. The 
ancient Egyptians had no word for 'politeness' or 'courtesy', and the closest word that would match the Judeo-Christian Western perception of 'politeness' would be ' $h{ }^{c}-h m s j$ (TLA ${ }^{\mathrm{ii}}$ 650008) meaning 'to behave properly'. However, this word only appears a limited number of times, and only in didactic texts; it does not appear in other contexts. The didactic genre is designed to express an idealised version of society. When compared with epistolary texts, often the idealised behaviour is not repeated in more practical communications. For example, in the Instructions of Ptahhotep, example 1 below, remaining silent and retaining self-control is voiced as a positive virtue when interacting face-to-face with people of varying social status.

\section{Example 1.}

If you come up against an aggressive adversary (in court),

One who has influence and is more excellent than you,

Lower your arms and bend your back,

For if you stand up to him, he will not give in to you.

You should disparage his belligerent speech

By not opposing him in his vehemence.

The result will be that he will be called boorish,

And your control of temper will have equalled his babble.

If you come up against an aggressive adversary,

Your equal, one who is of your own social standing,

You will prove yourself more upright than he by remaining silent,

While he speaks vengefully.

The deliberation by the judges will be somber,

But your name will be vindicated in the decision of the magistrates.

If you come up against an aggressive adversary,

A man of low standing, one who is not your equal,

Do not assail him in accordance with his lowly estate.

Leave him be, and he will confound himself.

Do not answer him in order to vent your frustration. .ii $^{\text {ii }}$

Additionally, in the Instructions of a Man for His Son, a silent man is equated with a just man (O. DeM 1266, rt.10). These tenets sound very similar to Judeo-Christian European courtly behaviour outlined by Watts (2003: 32-41), and if scholars focus on didactic texts alone, as Fox (1983) emphasised (see also Terkourafi[2011: 163]), then limited advancements in understanding politic behaviour can be made. The Late Ramesside Letters reveal that remaining silent was not a key feature in daily communications, and perhaps not reflective of normative behaviour, ${ }^{\text {iv }}$ where the ability to speak without constraint is a feature of superior style language. This is epitomised by Dhutmose, who states in one of the letters to his son Butehamun: $b n j w=j g r n=k h r=s$, 'I will not be silent to you concerning it'v (it refers to a shipment of spears), linguistically reflecting the superior/subordinate nature of the father/son 
relationship. Keeping silent in a possible aggressive situation only appears once in the letters, when the Chantress of Amun Hennutawj discovers she has been cheated out of grain by the men who transported it to Thebes. ${ }^{\text {vi }}$ Whether she kept silent during the event to demonstrate normative behaviour, or because she felt threatened, is unclear in the letter (Sweeney 1994; Quack 2008). What is clear is that the information presented above is reliant on the social relationship between the individuals involved and their perceived social status and distance, and that normative behaviour is difficult to determine with limited documentation.

How then can we begin to access user evaluations of 'politic' behaviour in the Late Ramesside Letters? A possible solution may be to reduce Watt's knowledge frame to the individual interaction between the interlocutors or a single communicative event, and then analyse the evaluation of behaviour expressed within the letter itself (Watts 2003: 262). This would reflect the interlocutors' compliance to the expected normative behaviour within the ongoing social interaction and whether it is judged to be appropriate for the specific situation (Fraser \& Nolen 1981; Fraser 1990; Terkourafi 2011: 177). However, yet again, within the Late Ramesside Letters, we are faced with a limited number of examples within the communicative events. Examples 2 and 3 come from the same letter written by Dhutmose to his son and provide user evaluations of behaviour. In example 2, after the formal introduction of the letter, Dhutmose writes to Butehamun to inform him of his journey south and his meeting with his superior Piankh. Here, Dhutmose quotes Piankh's words to him, revealing that Dhutmose traveling south was considered by Piankh to be appropriate to their ongoing social interaction, demonstrating that Dhutmose understood his superior's expectations of him.

\section{Example 2:}

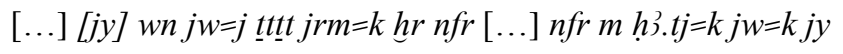

““[...(If you had not) come] then would I argue with you; but good [...that you found] goodness in your heart and you came", vii

\section{Example 3:}

bn $n f r$ p3j j.jri=k

'It is not good what you did' viii

Example 3 appears later in the letter in reference to Butehamun's failure to adhere to an earlier request act issued by his father, which was considered inappropriate to the specific situation. The father/son relationship represents a superior/subordinate relationship, but unlike the traditional superior/subordinate relationship included discussion about the family and more emotive language usage. Nonetheless, Dhutmose still expected to be treated as a superior individual in the social interaction; hence Butehamun's failure to complete his superior's request act was not normative behaviour for this relationship dynamic.

What becomes apparent is that the analysis of so-called 'politic' behaviour in Late Egyptian requires further study due to limitations in accessing user evaluations of behaviour (Bax \& Kádár 2011: 17). It is also clear that social order and hierarchy play an essential role in the evaluation of behaviour in both didactic and epistolary texts. Normative behaviour is in this way linked to the concept of 'face' (both examples 2 and 3 could be read as potential FTAs), in that for successful communication, and by extension relationship maintenance, to be achieved between the interlocutors, expectations that reflect the social dynamics of the interlocutors must be met: this is normative behaviour within this context. As such, knowledge frames cannot be used independent of other 'politeness' frameworks, and in this way, it is not possible to rely solely on studying first-order politeness within this context. It is essential to combine first- and second-order politeness for a more detailed analysis to occur. 


\subsection{Facework}

Following on from current discussions that politeness and facework should be considered separately (Watts 2003: 276; Bax \& Kádár 2011: 13; Kádár \& Haugh 2013: 50-52), this section will demonstrate the role 'face' played in relationship maintenance, both directly and indirectly, and discuss examples of when Brown \& Levinson's framework is both applicable and non-applicable to the Late Egyptian data in regards to FTAs. Due to the high frequency of letters that have survived written by the Scribe Dhutmose, a rare insight into the relationship he shared with his direct superior Piankh can be explored. The majority of these letters were written around Regnal Year 29 of Ramesses XI (c.1070 BCE) when Dhutmose was situated in southern Egypt, travelling between Thebes, Elephantine, and Nubia, and writing to his friends and family in Thebes to inform them of his situation. In example 4, Dhutmose describes his journey south and his relationship with the general:

\section{Example 4:}

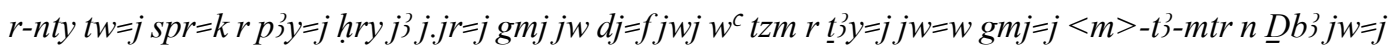

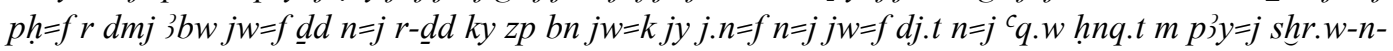
$\underline{h r}-\underline{h}$ 3.t $j w=f \underline{d} d n=j$ hsj Mnt.w

As follows: I have reached my superior. Oh, I discovered that he had sent a tsm boat to collect me when they found me in the middle of Edfu and then I met him in the town of Elephantine, he said to me, 'Another time you would not need to come', so he said to me. Then he gave to me bread and beer according to my previous custom, and he said to me 'Praise to Montu'. ${ }^{\text {ix }}$

It is clear that Piankh as the socially superior individual was expected not only to provide transportation for the scribe but also daily rations of bread and beer, a sentiment reiterated in examples 5 and 6 :

\section{Example 5:}

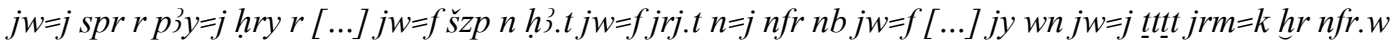

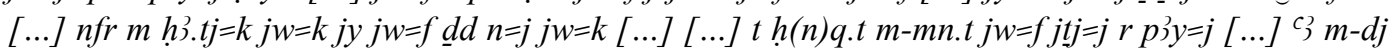
bt3 $m-b 3 h$ p $p 3 y=j$ hry

I have reached my superior at [...] he received me upon arrival and did every good thing for me. He (said to me) "[... If you had not] come, then I would argue with you; but, good [...that you found] goodness in your heart and you came". He said to me, "You shall [...] bread and beer daily". He took me to my (9) $[\ldots]$ great because of/for an offence before my superior. ${ }^{\mathrm{x}}$

\section{Example 6:}

$h r$ tw $=j m-\check{s} s$ zp-2 $m-{ }^{c} p 3 y=j$ hrry $b w-j r j=f n n j n=j$ di=f mjnj $n=j w^{c} m d q$.t $r-j w d$ hrw $55^{c} q . w-n-w n m m-$ $m n . t w^{c} n w j w=f$ šzp 5 hnw $n h(n) q .(t) m-m n . t m p 3 y=f b 3 k . w$

Now, I am all right with my superior! He does not neglect me. He has caused to gift me with one $m d q . t$-vessel every five days, five ordinary loaves daily, and a $n w$-vessel, which receives five hinmeasures of beer daily, from his wages. ${ }^{\mathrm{x}}$

Whilst some of the text in example 5 has lost its Sitz im Leben and is partially damaged, it is apparent that Dhutmose is writing to his son stressing the close relationship he shares with his superior, but the exact nature of the great offence mentioned is not clear. The two extracts demonstrate the importance of public 'face' within the relationship of superior/subordinate. From the viewpoint of Dhutmose, the scribe wishes to show the positive side of his relationship with the general and reinforce his elevated position with him. This in turn helps to support his social standing among his family and community members, especially when we consider that the Egyptians would read documents aloud and letters would have likely been recited to an audience of friends and family members. Yet, the extracts also help to reinforce the public 'face' of Piankh, as the letters sent by Dhutmose concerning him are never negative or critical towards the actions of his superior; threats or 'face-threatening' acts, i.e. negative comments, cannot be issued socially upwards. They can certainly be issued to those socially inferior, 
as demonstrated by Dhutmose in example 9 below, where he rebukes the laziness of an official left in charge of the Theban necropolis in his absence.

The perception of the wider community towards the relationship between Piankh and Dhutmose also plays an important role in the maintenance of the public 'face' of Dhutmose. In two separate letters sent to Dhutmose, the senders of the letters make reference to this relationship (example 7), both letters are sent to Dhutmose by men who appear to be of a similar social status:

\section{Example 7:}

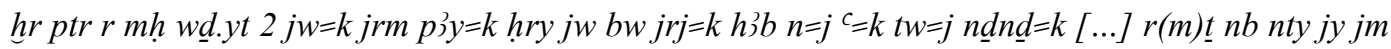
$m-\underline{h} d m t w=w \underline{d} d n=j$ tw=k $m-\check{s} s$ sw $n$ fr $m-b 3 h$ p $p 3 y=f$ hry $h r=w n=j m t r n=j$

Now, see, it is the second campaign that you are with your superior, yet you have not written to me about your condition. I am inquiring about you [...] from everyone who comes downstream from there (where you are), and they tell me that you are all right. 'He is good before his superior', so they tell me, confirming (it) to me. ${ }^{\text {xii }}$

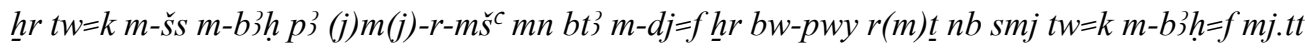

Now, you are all right before the general, there is no harm done to him. Now, no (v.1) man has reported you before him either. ${ }^{\text {xii }}$

These two separate statements not only reassure Dhutmose of the continuation of his public reputation and the maintenance of his own self-image within his wider community, but also act as a positive politeness strategy. By complementing Dhutmose on his good standing before the general, it reduces the threat to the scribe's positive-'face', and promotes good relations between the sender and recipient of the letter. This is a strategy present in the Late Ramesside Letters that is only used between men of equal stature or subordinates to their superiors. Generally the two individuals need to be well-acquainted with one another to fully utilise this politeness strategy.

Not all communication, however, was successful between the correspondents and a variety of differing FTAs and 'face-saving' acts can be found in the letters. An example of an individual attempting to restore his damaged 'face' can be found in example 8. The example is taken from a letter sent between two unknown individuals concerning an inappropriate joke made by the sender of the letter towards a third man, known only as the chief taxing minister; a high ranking official from the local Theban community. In turn the chief taxing minister has publicly damaged the 'face' of the recipient of this letter. Thus, example 8 is the sender's attempt to restore the relationship between them, and, perhaps by association, both their relationships with the chief taxing minister. The sender of the letter recognises the impingement made by the joke, but assigns blame for the joke's inclusion to another individual in order to reduce the degree of the FTA.

\section{Example 8:}

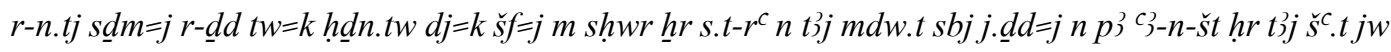

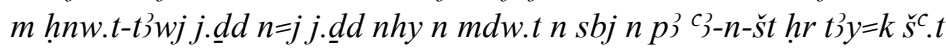

Furthermore, I have heard that you are angry and that you have made my respect contemptuous on grounds of these words of humour, which I said to the chief taxing minister in that letter, although it was Henuttawj who urged me to tell some humorous words to the chief taxing minister in my letter. $^{\text {xiv }}$

Joking is a basic positive politeness technique, intended to put the recipient at ease, and may also be used as an exploitation of politeness strategies as well, in attempts to redefine the impact of an FTA. Brown \& Levinson (1987: 124) argue that jokes may operate to redefine social variables between individuals, especially the social distance and the absolute ranking of impositions within the specific culture. In the example here, the joke has been interpreted by the recipient and chief taxing minister as 
inappropriate (see Hansen 2012), suggesting that the sender of the letter completely failed to comprehend the levels of social intimacy and status between the men involved. On this issue, Sweeney (1997: 73) comments that it is, 'possible to view this [example] as moral indignation, a reaction by the addressee to the sender's offence against the normative order'. In this case normative behaviour entailed adhering to the superior/subordinate relationship, which the joke failed to do. In an attempt for the sender of the letter to save his public 'face' in the eyes of the recipient, he blames Henuttawj for encouraging him to include the offensive joke in the letter, dissociating himself from the imposition. This is one of several strategies the author uses to minimise the effect of the quarrel; he also attempts to downplay his offence and performs extensive 'face-saving' acts. This neatly reflects Brown and Levinson's (1987: 187-190) negative politeness strategy 6, where, in order to satisfy the recipient's negative-'face' demands the sender of the letter must indicate the he is aware of them, and recognise any impingement made by making amends for the FTA, in this case the joke.

Brown and Levinson outline four ways to communicate regret or reluctance for the FTA: admit the impingement, indicate reluctance, give overwhelming reasons and beg forgiveness, all of which are enacted by the sender in his letter. The sender of example 8 embarks on an extended apology to beg forgiveness, listing evidence of his shared history with the recipient, and reinforcing the intimate relationship between the two men via a cornucopia of metaphors (Brown \& Levinson 1987: 123-124). By demonstrating his shared history with the recipient, the sender attempts to claim common ground with him and perform positive politeness strategies. For example, the phrase $m y j$.jri $i w w s j=k j w=j m$ p3 $p r$, 'Oh, you were born when I was in your house' demonstrates that they have always known each other. This theme of life-long friendship (and possible kinship) is demonstrated in other documents from this period found on the Theban west bank. In P. DeM V, rt.3 the phrase 'since I was a child until today' appears, and in P. DeM VI, rt.2-3, the following phrase is included, 'whilst you are with me like a brother forever when I am like a grown-up orphan with you' (Sweeney 1998: 103-106). Metaphors also take an important role in 'face-saving' acts, and family metaphors help to reinforce kinship. In this case, the sender writes that without the recipient's friendship, " $j w=j m n m h, w$, I am an orphan", stressing that he will be alone without his companion. The implication of referring to an orphan-like state acts as a politeness strategy to reduce the level of imposition, appealing to the recipient's positive 'face', implying that without this friendship the sender would be alone in the world, and thus stressing the importance of the friendship.

Many aspects of Brown \& Levinson's framework can be utilised for assessing facework in Late Egyptian, however, there is one sticking point: negative-'face'. Although, the apology given above reflects one of aspect of negative-'face' that can be used effectively, the very essence of negative-'face', that one's action be unimpeded, is not wholly appropriate. In a fundamentally hierarchical society, social power, and even to an extent social distance, is pre-determined and essential for successful communication, but is not negotiable within communicative events. Hence, socially superior individuals are free to criticise their subordinates without mitigating the FTA: it is simply not necessary. Example 9 represents a letter sent by an unknown individual, probably Dhutmose, to a scribe named Nesamunipet, who was left in charge of the Theban Necropolis in Dhutmose's absence.

\section{Example 9:}

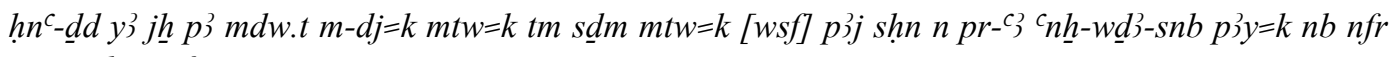
$n t j \mathrm{tw}=\mathrm{kjm}=f$

Furthermore: Oh! What is this matter concerning you? And that you do not listen, and you [are idle in the] commission of Pharaoh, LPH, your good lord, in which you are engaged.

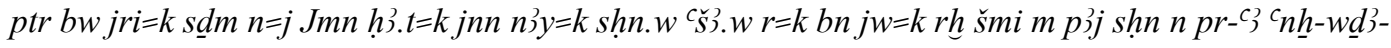
snb 
See, you do not listen to me; Amun is before you! Even if your commissions are too many for you, you know that you will not be able to walk out on this commission from Pharaoh, LPH. ${ }^{\mathrm{xv}}$

In example 9 several different issues concerning facework are in play as Dhutmose implies that Nesamunipet is lazy and failing to carry out his duties for the pharaoh after he has not completed the requests issued to him by Dhutmose, his superior. As such, Dhutmose has received words of complaint. The main problem here is that Nesamunipet failed to comply with the normative behaviour of fulfilling his superior's request acts. In this example Dhutmose openly criticises Nesamunipet, adding weight to the criticism by mentioning the pharaoh and the god Amun, the two highest authorities among men and the gods. A variety of competing FTAs are in play within this dynamic according to Brown \& Levinson. Firstly, Nesamunipet's inability to complete the request acts issued to him by Dhutmose in a previous letter has damaged both Dhutmose's negative-'face', by not completing them, and his positive 'face', due to letters of complaints he has received, which affect his overall public 'face' and his perceived standing among his community. Secondly, Nesamunipet's positive-'face' is damaged via Dhutmose's expressions of disapproval and criticisms, and, if we follow Brown \& Levinson (1987: 66) to the exact wording, his negative-'face' has been damaged by Dhutmose in regards to the following points: (i) orders and request (complete the previous request acts); (ii) remindings (Dhutmose reminds him of his duties); (iii) threats (Dhutmose uses the phrase Amun is before you, i.e. Amun is your witness, and repeats more than once that the commissions are for the king). However, Dhutmose, as the socially superior individual is free to intervene in the actions of his subordinates. This is part of expected behaviour, and, as such, there is no need for Dhutmose to mitigate the FTAs: he is free to make them. The power aspect of their relationship is fixed and threats are part of superior-style language, implying that adherence to a subordinate's negative-'face' was not necessary in a superior/subordinate communicative act.

\subsection{Discernment politeness}

As Kádár \& Culpeper (2010: 24) acknowledge 'another issue in historical politeness studies is the relationship between certain deferential (honorific) forms and strategies of humility and politeness' ${ }^{\text {xvi }}$ In the Late Ramesside Letters these two features become key in successful communication the further separated socially the superior and subordinate interlocutors become. As Junker (2010: 195-196) similarly expresses for Middle English, the linguistic forms under review here cannot really be seen to be 'face-saving' acts as Brown \& Levinson (1987: 178-187) classify them since they take into consideration the power differential between the interlocutors. Instead they can be considered to be examples of discernment politeness, 'where linguistic forms are chosen in response to social context and not a strategy to avert a 'face' threat' (Junker 2010: 196).

An example of this is the relationship demonstrated between the General Piankh and Butehamun, who, in spite of being the son of Dhutmose, had a far more distant superior/subordinate relationship with the General Piankh than his father. P. BM EA 10375, a letter sent by key necropolis officials, including Butehamun, to the General Piankh, best demonstrates the formality of the superior/subordinate relationship. The letter begins with a very extensive formal introduction, the longest in the corpus of letters, in order to demonstration the social distance between the senders and the recipient of the letter. The concluding line of the formal introduction containing the blessings differs slightly from those found between family members and close friends. Instead of the phrase $m t w=j m h q n j=j j m=k$, 'and that I may fill my embrace with you', or one of its variants, the phrase $m t w=n$ mh jr.t=tn $m$ ptr $=k$, 'and that we may fill our eye with the sight of you', is used. This slight alteration in the address to an individual vastly superior to the senders of the letter reaffirms this social position, as intimacy is closely linked with social status, and as such, it would be inconceivable to the necropolis officials to have intimate contact with their superior.

This adaptation of language to fit such a distant superior/subordinate relationship is also reflected in the opening lines of the main body of text. Here, instead of the phrase $s \underline{d} m=j m d w n b j . h 3 b=k n=j h r r=w$, 'I 
have heard every matter that you sent to me', the phrase $s \underline{d} m=n m d w . t n b j . h 3 b n=n$ p $y=n n b h r=w$, 'we have heard all matters that our lord has sent to us', is used. This is simply because the first version of the phrase is most commonly used between either superiors to their subordinates or between individuals of equal social status. The latter phrase is used to convey the necessary level of deference when subordinates address their superiors; it is not possible for them to address them in the same manner as a family member or social equal. The honorific form of $p 3 y=n n b$ is used to stress the social distance between the necropolis officials and the general; it represents a direct grammatical encoding of the relative social status between the participants involved reinforcing the superior/subordinate relationship (Brown \& Levinson 1987: 276).

The letters also contain examples of frequently used phrases that possess interpersonal dimensions, which may be interpreted as conventional forms of letter writing (Kádár \& Haugh 2013: 140-148). These phrases seem to hold a deeper cultural significance and perhaps even reflect a form of 'politeness'. For example, the phrase wnn $t^{3} y=j \check{s}^{c}$. $t$ spr $r=k \ldots$.., 'when my letter reaches you...' appears in many of the letters directly before an imperative request act, it is used by superiors to their subordinates and between individuals who appear to be socially equal; its role in this context seems to be to mitigate any possible FTAs due to the request act:

\section{Example 10-11 (socially equal individuals):}

Ex. 10: ... wnn t3y $=j \check{s} c$. $t$ spr $r=k$ tm pri $r$ $m 33 \underline{h} \underline{h}$

... when my letter reaches you, do not (11) go out to look at the winnowing ... xvii

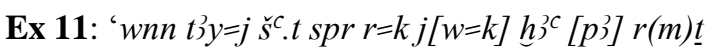

When my letter reaches you, you shall (9) release this man ... xviii

Examples 12-14 (superior individuals writing to subordinates):

Ex. 12: $w n n t 3 y=j \check{s}$. $t$ spr $r=k j w=k h 3 b n=j{ }^{c}=k$

When my letter reaches you, you should write to me about your condition... ${ }^{\text {ix }}$

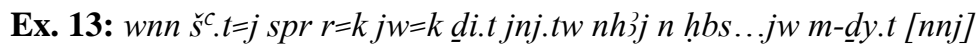

When my letter reaches you, you shall cause to have sent some cloth ... Do not be neglectful. ${ }^{\mathrm{xx}}$

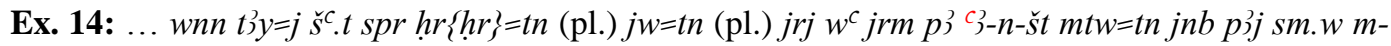
$j r j n n j, \ldots$ when my letter reaches you, you shall join up with the chief taxing minister and fence in this pasturage. Do not be neglectful. ${ }^{\mathrm{xxi}}$

Examples 13 and 14 come from letters sent by the General Piankh, and it is notable that after the imperative request act, for which the FTA is mitigated by the inclusion of 'when my letter reaches you', it is necessary to remind the recipient of the sender's social superiority by including the statement 'do not be neglectful'. On one hand the FTA is mitigated, whilst on the other the expectations of the social dynamic are reinforced.

In some ways, ancient Egypt shares some similarities to the Japanese term Wakimae, which Ide (1989: 230) defines as 'showing ones sense of place or role in a given situation according to social convention', this includes being polite to those of a higher social position and who are perceived to have more power. Ide and Matsumoto have both argued that the individual social person in Japanese culture only has individual status by virtue of belonging to a social group (see discussion by Watts 2003: 82). The same could be said of the societal structure of the community portrayed in the Late Ramesside Letters. Dhutmose has an esteemed position with his superior, the General Piankh, and because of this his son and other family members also have an elevated position in the community; they belong to Dhutmose's household and are expected to behave and communicate in a certain way. Within the Late Ramesside 
Letters communication between vastly separated social groups is not apparent. For example, in communication between the General Piankh and coppersmiths (often unnamed individuals) all communication is passed between Dhutmose and Butehamun as intermediaries of the request act, as in example 15:

\section{Example 15:}

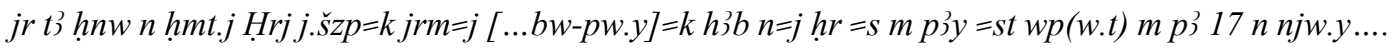

As for the commission of the coppersmith Hori that you received with me (14) [...], you have not written to me about it, namely, its order consisting of the 17 spears.... ${ }^{x i i}$

In example 15, it is apparent that the coppersmith Hori is working under the direction of Dhutmose, who in turn is under the direction of the General Piankh. Thus Hori has individual status in the communicative act via his relationship with Dhutmose, not Piankh. Example 16 is the response by Butehamun to his father's request, providing testimony as to the completion of the request act initiated by Dhutmose. This time, the coppersmith is not individually named, but only referred to by his professional status:

\section{Example 16:}

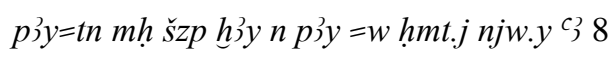

your payment has been received and measured by their coppersmith: great spears 8. xxiii

In both examples 15 and 16 no direct request has been made to the coppersmiths themselves. All requests have passed through an intermediary, in this case Butehamun, who then reissues the request verbally to the men. In the letters, the person who initiates imperative requests is generally the socially superior individual in the social dynamic. Thus, community groups separated by social status emerge in the letters, each group needing to adhere to set relationship dynamics that form normative behaviour between the differing social levels (see Sweeney 2001: 232).

\section{Courtesy vs. Politeness}

In light of the discussion above it is possible to explore Sweeney's (2001: 242) concept of Courtesy, which she breaks into status, cost \& benefit, and connection. Junker (2010: 188) in his study of the term curteisie in works by Chaucer, states that curteisie refers to 'a virtue to be aspired to but also to a form of appropriate behaviour that fits both the situation in which it occurs and the social status of the interactants'. From these origins 'courtesy' has permeated into the modern world, a politeness-related term full of western Judeo-Christian connotations, which relates to how a person feels and sense of self are supported or aggravated in conversation (Kádár \& Culpeper 2010: 9). There is no corresponding notion that is adequately understood in Ancient Egyptian - the same can be said for 'politeness', of course - for courtesy to be used in this situation in a manner that does not bring with it modern connotations (contra: Terkourafi 2011). Sweeney's approach to courtesy echoes a reduced form of the maxims proposed by Leech in his Politeness Principle and Brown \& Levinson's social distance and relative power, opening up the analysis to ambiguity and failing to take into account the non-negotiable social position of the correspondents. However, in light of this, Sweeny's categories are relevant for status, due to the importance of hierarchy, and connection, which allows for the identification of emotive language between family members, something not prioritised in Brown \& Levinson. There is such an overlap between these two categories within the superior/subordinate relationship, i.e. between father/son, that to develop the framework further it seems prudent to combine these two points in order to go beyond the current framework established by Brown \& Levinson.

Cost \& benefit is a far more difficult variable to identify within the Late Ramesside Letters, as it is not applicable to interlocutors of different social status, as subordinates were expected to complete request acts made to them by their superiors: it is not a negotiable interaction. Sweeney (2001: 241) highlights 
this, stating that the factor of cost \& benefit is more relevant to socially equal individuals, and assesses a wider range of Late Egyptian data where gift giving or flattery are at times used to encourage individuals to complete the request act (Sweeney 1998). Yet, this is also not a straightforward division. For example, Sweeney (2001: 244) states that 'if the recipient is not very important to the sender, or is in any case duty bound to accomplish this task, the sender will not bother to point out the benefits of a given course of action'. To this purpose, Sweeney uses the request act in P. BN 197 VI (Černý 1939: 64; Wente 1967: 76-77; 1990: 199-200), in which Butehamun asks his friend Shedsuhor to watch over his father at night on the boat whilst they both travel south to Nubia. Sweeney (2001: 244) argues that Shedsuhor is under no obligation to take care of Dhutmose, but does so at considerable cost to himself as a favour to Butehamun. However, Dhutmose was a high ranking scribe with an important position within the expedition group and before his superior, not to mention that he was also of an older generation and of ill health. Socially, it could be seen that Shedsuhor was expected to care for his superior Dhutmose as part of his position within the social community, ${ }^{\mathrm{xxiv}}$ and that normative behaviour would require him to (consider wakimae). Additionally, Shedsuhor could gain more status by strengthening his relationship with Dhutmose, especially raising his profile with the General Piankh.

Ancient Egyptian culture was based upon a strict hierarchical system, and modern politeness frameworks are not really designed to take this into account. In the Late Ramesside Letters the superior/subordinate relationship is expressed not only via the construction and context of the utterances themselves but also the format of the letter and grammar used, all of which must be combined to ensure successful communication between interlocutors. These deferential aspects are certainly necessary for successful communication with a superior in a communicative event, but whether they are manifestations of the superior/subordinate relationships or examples of 'polite' behaviour is difficult to discern (Brown \& Levinson 1987: 182-183; Kádár \& Culpeper 2010: 24-25). Hence utilising discernment politeness is essential for establishing patterns within the communication and isolating further characteristics of this relationship and also provide a strong basis for the application of facework. Assessing politic behaviour in a wider sense is more difficult to determine due to limited data. Watt's politeness knowledge frames of politic behaviour can be used so long as they explore user observations of normative behaviour, expressed using both the letter context and the encoding of the interlocutors social identities. First-order politeness must be used in conjunction with other forms of second-order politeness frameworks, none can be used in isolation, and the analysis of communicative events/utterances many require simultaneous usage of these frameworks. Brown \& Levinson's negative-'face' is perhaps a key point for consideration looking forward, as the superior/subordinate relationship certainly allowed for those socially superior individuals to freely impede the actions of their subordinates without it being considered to be an FTA. Of course, this article only examines one corpus of texts and so the development of politeness research in both Late Egyptian and other stages of Ancient Egyptian, requires the creation of a larger data set. In addition, impoliteness has not been touched upon here.

\section{Concluding Remarks}

Linguistically, grammatically, and structurally, the Late Ramesside Letters are supported by a strict underlying adherence to social status. Within this context all interaction is reliant on the interlocutors understanding their (perceived) position within their community and meeting the expectations of each other in communication; this is how normative behaviour is expressed within the microcosm of the corpus. Yet, separating communication necessary for successful social interaction between superior/subordinate individuals and possible instances of 'politeness' is difficult to identify. This is the next task facing politeness research in Late Egyptian, and indeed in other stages of Ancient Egyptian as well, a task that will not only involve the diachronic study of the language but a comparison with other projections of politeness across the ancient world. A key problem with progressing forward with such an analysis is the lack of meta-language for the ancient world when attempting to assess so-called 'politeness' in general, and certainly there is no such current singular framework robust enough, to not 
only adapt to issues faced by scholars working on dead languages, but also to take into consideration the deeply ingrained sense of hierarchy and social order (Sweeney 2001: 233). This maybe the true potential of studying politeness phenomenon in dead languages, progressing the discussion of social power and distance forward, as well as challenging the feasibility of politeness frameworks primarily designed for modern languages and cultures. This paper has attempted to highlight some of the issues in Late Egyptian and the potential for further analysis of politeness phenomena in the Late Ramesside Letters. It is not possible at this stage to rely on any single politeness framework or a first-order approach, but rather it is necessary to combine different frameworks to produce sustainable conclusions.

\section{Bibliography}

Allen, James. 2005. Middle Egyptian: an introduction to the language and culture of hieroglyphs. Cambridge: Cambridge University Press.

Bakir, 'Abd El-Mohsen. 1970. Egyptian epistolography from the eighteenth to the twenty-first dynasty (Bibliothèque d'Étude 48). Cairo: Imprimerie de l'Institut français d'archéologie orientale.

Bax, Marcel. 2010. Epistolary presentation rituals: facework, politeness, and ritual display in early Modern Dutch letter-writing. In Jonathon Culpeper \& Dániel Kádár (eds.), Historical (im)politeness. 37-86. (Linguistic Insights 65) Bern, Berlin, Bruxelles, Frankfurt am Main, New York, Oxford, Wein: Peter Lang.

Bax, Marcel. 2011. An evolutionary take on (im)politeness: three broad developments in the marking out of socioproxemic space. Journal of Historical Pragmatics 12. 255-282.

Bax, Marcel \& D. Kádár. 2011. The historical understanding of historical (im)politeness: introductory notes. Journal of Historical Pragmatics 12. 1-24.

Biber, Douglas \& E. Finegan. 1989. Drift and the Evolution of English-Style: a history of three genres. Languages 65. 487-517.

Biber, Douglas \& E. Finegan. 1992. The linguistic evolution of five written and speech-based English genres from the $17^{\text {th }}$ to the $20^{\text {th }}$ Century. In Matti Rissanen, Ossi Ihalainen, Teerttu Nevalainen \& Irma Taavitsainen (eds.), History of Englishes, new methods and interpretations in historical linguistics, 688-704. Berlin/New York: Mouton de Gruyter.

Bierbrier, Morris. 1975. The Late New Kingdom in Egypt (c. 1300-664 BC): a genealogical and chronological investigation (Liverpool Monographs in Archaeology and Oriental Studies). Warminster: Aris and Phillips Limited.

Blum-Kulka, Shoshana. 1987. Indirectness and politeness in requests: same or different? Journal of Pragmatics 11. 131-146.

Blum-Kulka, Shoshana. 1990. You don't touch lettuce with your fingers: parental politeness in family discourse. Journal of Pragmatics 14. 259-288.

Blum-Kulka, Shoshana. 1992. The metapragmatics of politeness in Israeli society. In Richard J. Watts, Sachiko Ide \& Konrad Ehlich (eds.), Politeness in language: studies in its history, theory and practice, 259-288. Berlin: Moulton de Gruyter.

Bridge, Edward. 2010. Polite language in the Lachish Letters. Vetus Testamentum 60(4). 518-534.

Brown, Penelope \& S. Levinson. 1987. Politeness: some universals in language usage (Studies in Interactional Sociolinguistics 4). Cambridge: Cambridge University Press.

Černý, Jaroslav. 1939. Late Ramesside Letters (Bibliotheca Aegyptiaca 9). Brussels: Fondation égyptologique reine Élisabeth.

Černý, Jaroslav. 1973. A community of workmen at Thebes in the ramesside period (Bibliothèque d'Étude 50). Cairo: l'Institut français d'archéologie orientale.

Demarée, Robert J. 2006. The Bankes Late Ramesside Papyri (The British Museum Research Publications 155). London: British Museum Press.

Donker van Heel, Koen \& B. Haring. 2003. Writing in a workman's village: scribal practice in ramesside Deir el-Medina (Egyptologische Uitgaven 16). Leiden: Nederlands Instituut voor het Nabije Oosten.

Eelen, Gino. 2001. A critique of politeness theories. Manchester: St. Jerome.

Enlich, Konrad. 1992. On the historicity of politeness. In Richard J. Watts, Sachiko Ide \& Konrad Ehlich (eds.), Politeness in language: studies in its history, theory and practice, 71-107. Berlin: Moulton de Gruyter.

Fox, Michael. 1983. Ancient Egyptian rhetoric. Rhetorica: A Journal of the History of Rhetoric 1. 9-22.

Fraser, Bruce. 1990. Perspectives on politeness. Journal of Pragmatics 14(2). 219-236.

Fraser, Bruce \& W. Nolen. 1981. The association of deference with linguistic form. International Journal of the Sociology of Language 27. 93-109.

Gibson, Andrew \& R. Morrison. 2007. What is a letter? In Ruth Morello \& Andrew Morrison (eds.) Ancient letters: Classical and Late Antique epistolography, 1-16. Oxford: Oxford University Press.

Goffman, Evring. 1967. Interaction ritual: essays in face-to-face behaviour. Garden City, NY: Doubleday. 
Goffman, Evring. 1969. The Presentation of Self in everyday life. Harmondsworth: Penguin.

Grice, Paul. 1975. Logic and Conversation. In Peter Cole \& Jerry Morgan (eds.), Syntax and semantics, vol. 3 : Speech acts, 41-58. London: Academic Press.

Hansen, Nicole. 2012. Still laughing after all these years: an ancient Egyptian 'joke' survives the millennia. Journal of the Society for the Study of Egyptian Antiquities 38: 77-79.

Ide, Sachiko. 1989. Formal forms and discernment: two neglected aspects of universals of linguistic politeness. Multilingua 8. 223-248.

Ide, Sachiko. 1992. Gender and function of language usage: quantitative and qualitative evidence from Japanese. Pragmatics and Language Learning 3. 117-129.

Janssen, Jac J. 1991. Late Ramesside Letters and communications (Hieratic Papyri in the British Museum 6). London: British Museum Press.

Jucker, Andreas. 2010. "In curteisie was set ful muchel hir lest": politeness in Middle English. In Jonathon Culpeper \& Dániel Kádár (eds.), Historical (im)politeness. 175-200 (Linguistic Insights 65). Bern, Berlin, Bruxelles, Frankfurt am Main, New York, Oxford, Wein: Peter Lang.

Jucker, Andreas. 2011. Positive and negative face as descriptive categories in the history of English. Journal of Historical Pragmatics 12: 178-197.

Junge, Friedrich. 2005. Late Egyptian grammar: an introduction (Griffith Institute publications). Oxford: the Alden Press.

Kádár, Dániel. 2010. Exploring the Historical Chinese polite denigration/evaluation phenomena. In Jonathon Culpeper \& Dániel Kádár (eds.), Historical (im)politeness (Linguistic Insights 65), 117-146. Bern, Berlin, Bruxelles, Frankfurt am Main, New York, oxford, Wein: Peter Lang.

Kádár, Dániel \& S Mills. 2013. Rethinking discernment. Journal of Politeness Research 9: 133-158.

Kádár, Dániel \& J. Culpeper. 2010. Historical (Im)politeness: An Introduction. In Jonathon Culpeper and Dániel Kádár (eds.), Historical (im)politeness (Linguistic Insights 65), 9-36. Bern, Berlin, Bruxelles, Frankfurt am Main, New York, oxford, Wein: Peter Lang.

Kádár, Dániel \& M. Haugh. 2013. Understanding politeness. Cambridge: Cambridge University Press.

Kerbrat-Orecchioni, Catherine. 2011. From good manners to facework: politeness variations and constants in France, from the classic age to today. Journal of Historical Pragmatics 12: 133-155.

Lesko, Barbara. 1999. 'Listening' to the ancient Egyptian woman: letters, testimonials and other expressions of self. In Emily Teeter \& John Larson (eds.), Gold of praise: studies in honour of Edward F. Wente (Studies in Ancient Oriental Civilisation 58), 247-254. Chicago: The Oriental Institute of the University of Chicago.

Morello, Ruth \& A. Morrison. 2007. Ancient letters: classical and late antiquity epistolography. Oxford: Oxford University Press.

Nevala, Minna. 2010. Keeping up appearences: facework in self- and addressee-orientated person reference. In Jonathon Culpeper \& Dániel Kádár (eds.), Historical (im)politeness (Linguistic Insights 65), 147-174. Bern, Berlin, Bruxelles, Frankfurt am Main, New York, oxford, Wein: Peter Lang.

Palander-Collin, Minna. 2009. Patterns of interaction: self-mention and addressee inclusion in the letters of Nathaniel Bacon and his correspondents. In Arja Nurmi, Minna Nevala \& Minna Palander-Collin (eds.) The language of daily life in England (1400-1800), 53-74. Amsterdam: John Benjamins.

Palander-Collin, Minna, M. Nevala \& A. Nurmi .2009. The language of daily life in the history of English: studying how macro meets micro. In Arja Nurmi, Minna Nevala \& Minna Palander-Collin (eds.) The language of daily life in England (1400-1800), 1-26. Amsterdam: John Benjamins.

Porten, Bezalel. 1996. The Elephantine Papyri in English: three millennia of cross-cultural continuity and change (Documenta et Monumenta Orientis Anitqui 22). Atlanta: Society of Biblical Literature.

Quack, Joachim. 2008. Henuttawis machtlose Unschuld. Zum Verständnis von LRL Nr. 37. In Charles Gallois, Pierre Grandet, Laure Pantalacci (eds.), Mélanges offerts à François Neveu par ses amis, élèves et collègues à l'occasion de son soixante-quinzième anniversaire, (Bibliothèque d'étude 145), 259-263. Cairo: Institut français d'archéologie orientale du Caire.

Ridealgh, Kim. 2013. Yes sir! an analysis of the superior/subordinate relationship in the Late Ramesside Letters. Lingua Aegyptia: Journal of Egyptian Language Studies 21: 181-206.

Simpson, William Kelly, (ed.). 2003. The literature of ancient Egypt: an anthrology of stories, instruction and poetry. New Haven: Yale University Press

Sweeney, Deborah. 1994. Henuttawy's guilty conscience. (Gods and grain in Late Ramesside Letter no. 37). Journal of Egyptian Archaeology 80. 208-212.

Sweeney, Deborah. 1997. Offence and reconciliation in ancient Egypt: a study of Late Ramesside Letter No. 46. Göttinger Miszellen: Beiträge zur ägyptologischen Diskussion 158. 63-79.

Sweeney, Deborah. 1998. Friendship and frustration: a study on Papyri Deir el-Medina IV-VI. Journal of Egyptian Archaeology 84. 101-122. 
Sweeney, Deborah. 2001. Correspondence and dialogue: pragmatic factors in Late Ramesside Letter writing, (Ägypten und Altes Testament: Studien zu Geschichte, Kultur und Religion Ägyptens und des Alten Testaments 49). Wiesbaden: Harrassowitz.

Terourafi, Marina. 2011. From Politeness1 to Politeness 2: tracking norms of im/politeness across time and space. Journal of Politeness Research 7. 159-185.

Van der Walle, Lieve. 1993. Pragmatics and classical Sanskrit: a pilot study in linguistic politeness, (Pragmatics and Beyond New Series 28). Amsterdam: John Benjamins.

Watts, Richard. 2003. Politeness, (Key Topics in Sociolinguistics). Cambridge: Cambridge University Press.

Watts, Richard. 2011. A socio-cognitive approach to historical politeness. Journal of Historical Pragmatics 12: 104-132.

Wente, Edward. 1967. Late Ramesside Letters, (Oriental Institute of Chicago Studies in Ancient Oriental Civilisation 33). Chicago: University of Chicago Press.

Wente, Edward. 1990. Letters from Ancient Egypt, (Society of Biblical Literature: Writings from the Ancient World 1). Atlanta: Scholars Press.

${ }^{\mathrm{i}}$ The letters are written in Late Egyptian, the third stage in the development of writing system used in Egypt from Dynasty 0 (c.3150 BCE) onwards until the introduction of Arabic to Egypt in the seventh Century AD. Written using two different scripts, hieroglyphic and hieratic, Ancient Egyptian is a highly sophisticated language system that incorporates both phonetic signs and classifier(s) into individual lexemes, which then combined to form grammatical sentences, expressing tense, aspect, mood and voice. Ancient Egyptian belongs to the Afro-Asiatic language family, and is related to Semitic languages, such as Arabic, Ethiopic, and Hebrew, as well as to Hamitic languages, such as Berber and Cushitic (Allen 2005: 1). Thousands of written sources survive today from different points in the evolution of this iconic culture, and the Late Ramesside Letters form one of the largest epistolary corpora. However, it must be remembered that the written word in Egypt was the language of the elite and scribal classes, and was a wholly masculine domain. There are minimal surviving texts by women and whether they authored these texts themselves is questionable.

ii TLA = Thesaurus Linguae Aegyptiae, the central online dictionary for Ancient Egyptian, www.aaew.bbaw.de/tla/index.html.

iii Simpson et al. 2003: 131-132, maxims 2-4.

iv Terkourafi (2011: 163) provides a limited discussion of ancient Egyptian didactic texts, only discussing one text with limited understanding of the social context and other text genres of Egypt, stating that they are the "earliest writings about politeness'. This is both factually questionable and ideological inaccurate: these texts only reflect the normative behaviour as expressed by the author and can only be applied to those of a literate and elite social class. More importantly, they deal with face-to-face communication and do not take into account the expectations built-in to superior/subordinate relationships, which cannot be solely explained as 'polite'. Subsequently, didactic literature cannot be seen to be reflective of desired behaviour for the whole of Egyptian society. Terkourafi's (2011: 177-178) later reference to morals is also not appropriate for the ancient Egyptian data, and the meaning of the text is misinterpreted by Terkourafi. She states that the passage from the Instructions of Ptahhotep reflects the amalgamation of politeness and morality and that they were closely linked with the divine. This is not an accurate reading of the passage, which rather reflects that the social order of Egypt was fixed and that social advancement was in the hands of the gods, i.e. luck. The discussion by Terkourafi demonstrates that it is not possible to utilise ancient sources in the discussion of 'politeness' phenomena without a deep understanding of the socio-textual context from which the texts originates, especially when attempting to apply modern JudeoChristian terminology, such as morality, to an ancient culture.

v P. Turin Cat. 2026, rt.18; Černý 1939: 72; Wente 1967: 83-85; 1990: 189-190.

vi P. Geneva D 191; Černý 1939: 57-60; Wente 1967: 71-4; 1990: 174-5.

vii P. BN 199 V-IX+196 V+198 IV, rt.6-rt.7; Černý 1939: 5; Wente 1967: 21-24; 1990: 186-187.

viii P. BN 199 V-IX+196 V+198 IV, v.4; Černý 1939: 6; Wente 1967: 21-24; 1990: 186-187.

ix P. Turin Cat. 1972, rt.5-rt.8; Černý 1939: 7; Wente 1967: 24-27; 1990: 185-6; Porten 1996: 65-68.

${ }^{x}$ P. BN 199 V-IX+196 V+198 IV, rt.5-rt.9; Černý 1939: 5; Wente 1967: 21-24; 1990: 186-187.

xi P. BM EA 10326, rt.11-rt.12; Černý 1939: 18; Wente 1967: 37-42; 1990: 190-192.

xii P. BN 198 I, rt.16-v.3; Černý 1939: 66; Wente 1967: 78-79; 1990: 198-199.

xiii P. BM EA 10419, rt.8-v.1; Janssen 1991: 16-20.

${ }^{\text {xiv }}$ P. BN 198 II, rt.4-rt.7; Černý 1939: 67; Wente 1967: 79-81; 1990: 173.

${ }^{x v}$ P. BN 198 III, rt.3-rt.5, v.3-v.4; Černý 1939: 68-69; Wente 1967: 81-82; 1990: 172-173.

xvi In an excellent article reconsidering discernment politeness by Kádár \& Mills, they state 'if we accept Ide's claim that discernment is a matter of degree and it exists in every culture and language, including non-honorificrich ones, it is logical to argue that discernment should be interpreted as observance of whatever counts as normatively conventional, and potentially ritualistic, within a society' (2013: 147). This is an adapt point to raise 
and is something that certainly warrants further discussion in a separate article, as discernment politeness is essential to the analysis of 'politeness' in the ancient world.

xvii P. Phillips, rt.10-rt.11; Černý 1939: 29; Wente 1967: 47-49; 1990: 196-197.

xviii P. Turin Cat. 1979, rt.8-rt.9; Černý 1939: 43; Wente 1967: 58-59; 1990: 177.

xix P. BN 198 I, v.5-v.6; Černý 1939: 67; Wente 1967: 78-79; 1990: 198-199.

${ }^{x x}$ P. BN 197 V, rt.2-rt.4; Černý 1939: 35; Wente 1967: 52-53; 1990: 182.

xxi P. BN 199 I, rt.2-rt.4; Černý 1939: 53; Wente 1967: 68-69; 1990: 202.

xxii P. Turin Cat. 2026, rt.13-rt.14; Černý 1939: 72; Wente 1967: 83-85; 1990: 189-190.

xxiii P. Geneva D 407, 1a-2a; Černý 1939: 16; Wente 1967: 33-37; 1990: 187-188.

xxiv Sweeney (2001: 233) does mention that there is an 'obligation of members of society to look after each other', but does not discuss this in relation to her category cost \& benefit. 